\title{
Barbara Jane Gillespie: A Tribute to a True Professional
}

$\mathrm{O}_{\mathrm{p}}^{\mathrm{n}}$ J January 18, 2012, CSHP and the profession of hospital pharmacy in Canada lost one of its true professionals. Jane Gillespie (b. April 24, 1944) was raised in Ontario and graduated from the Faculty of Pharmacy, University of Toronto, in 1966. The Pharmakon yearbook notation for Jane reads "Don't believe that small girls aren't mischievous", and so began her life in pharmacy.

Jane's career in hospital pharmacy took off when she accepted the position of director at York Central Hospital in Richmond Hill, Ontario. York Central was one of the first small hospitals to implement unit-dose drug distribution and computerized pharmacy systems. Under the leadership of Miss Gillespie (as she was known to staff and colleagues alike), the department thrived, with staff members following a philosophy of continually sharing knowledge among colleagues. Miss Gillespie was recognized for her development and mentorship of many of the profession's highly accomplished practitioners.

Jane held strong principles in all aspects of her personal and professional life. In return, her staff responded with pride under her tutelage. It is noteworthy that several of Jane's lifelong friends came from the management team at York Central Hospital. Her efforts and accomplishments were recognized when Jane moved on to the challenges of pharmacy at The Hospital for Sick Children in the early 1980s.

During her career, Jane routinely encouraged staff to maintain an active presence in the Canadian Society of Hospital Pharmacy (CSHP), a philosophy for which she was a capable role model. She served on CSHP committees and Council in the 1970s, progressing to the position of President in 1979/1980. One of the highlights of her presidency was participation in the Pan Pacific Conference, which explored the rapidly expanding "clinical pharmacy" practice model. As Jane reported, ${ }^{1}$ issues of the day included "the need to establish an adequate technical support base to free the pharmacists for patient orientated duties" and "liberate your pharmacists or languish"- topics that remain "hot" to this day.

Jane's next challenge within CSHP was the editorship of the Canadian Journal of Hospital Pharmacy, which was being transferred east from Saskatoon after 20 years under the guidance of Professor Jack L Summers and colleagues. For Jane, the challenge was simple (despite the boxes and boxes of the Journal's history that were transported across the country), as she described in an editorial in CJHP: "the desire to share knowledge with associates and the ability to learn from the experience of others is the mark of a vigorous and dedicated professional."

After half a decade as editor of the CJHP, Jane's next challenge was CSHP's Research and Education Foundation. Through her dedication and commitment, the Foundation was able to redirect fundraising and member support efforts toward its present robust status.

Jane made an indelible contribution to CSHP. Her passion and commitment were exceptional. Yet despite her extraordinary professional commitment, Jane found time to enjoy her personal life through travel, her cottage, and golf at the Ladies Golf Club of Toronto. B Jane Gillespie will be sadly missed by her many friends and colleagues. She made an outstanding contribution to her profession.

- Jim Mann, with assistance from Bev Hales and Bill Wilson

References

1. Gillespie BJ. The Pan Pacific Clinical Pharmacy Conference. Can J Hosp Pharm 1979;32(6): 175 .

2. Gillespie BJ. Twenty years [editorial]. Can J Hosp Pharm 1982;35(1):5. 